\title{
Haemolysis Complicating Viral Hepatitis in Patients with Glucose-6-phosphate Dehydrogenase Deficiency
}

\section{Summary}

Out of 20 patients with viral hepatitis whose glucose-6phosphate dehydrogenase (G-6-PD) levels were normal, $14 \mathrm{had}$ clinical evidence of a mild to moderate degree of haemolysis but in all the patients.studied the half life of chromium-51-labelled red cells was shortened.

Out of 18 viral hepatitis patients deficient in G-6-PD 17 had clinical evidence of haemolysis, and in eight this was more severe than in the group with normal G-6-PD values. Massive intravascular haemolysis occurred in four, three of whom died. The massive haemolysis was attributed to the presence of additional drug-induced oxidative stress to the G-6-PD-deficient red cells.

\section{Introduction}

A mild to moderate degree of haemolysis has been reported in patients with viral hepatitis (Pitcher and Williams, 1963). Occasionally severe haemolysis with haemoglobinuria occurs, and in these patients coexisting erythrocyte glucose-6-phosphate dehydrogenase (G-6-PD) deficiency has frequently been found (Salen et al., 1966; Clearfield et al., 1969; Phillips and Silvers, 1969; Kattamis and Tjortjatou, 1970). It was suggested that viral hepatitis per se provoked the severe haemolysis in the enzyme-deficient patients but drugs taken during the course of the illness may also have been responsible.

During 1962-71 we studied 18 G-6-PD-deficient patients suffering from viral hepatitis. Of these, three died after acute massive haemolysis. So far as we are aware this is the first paper to record death in patients with a combination of these two disorders. In addition the results of an investigation to determine the magnitude and possible cause of haemolysis in G-6-PD-deficient patients with viral hepatitis are presented.

\section{Patients and Methods}

Twenty G-6-PD-normal and 18 G-6-PD-deficient patients suffering from viral hepatitis were studied. The second group comprised consecutive patients admitted during the 10-year period 1962-71 to the University Department of Medicine at this hospital. All were adult southern Chinese, and though G-6-PD deficiency in this population is heterogeneous in type (Chan and Todd, 1972) our subjects had enzyme levels below $20 \%$ of normal when determined in the "steady" state. As the degree of haemolysis was similar among the different variants the results were not analysed according to the G-6-PD type. There were three female patients in each of the two groups.

The diagnosis of viral hepatitis was based on typical clinical features and laboratory findings of raised serum transaminase levels. The levels of serum total bilirubin and aspartate and

T. K. CHAN, M.B., M.R.C.P., Senior Lecturer

DAVID TODD, M.D., F.R.C.P., Professor of Medicine alanine transaminases (SGOT and SGPT) were determined on the AutoAnalyzer. The presence of hepatitis- $B$ antigen (HBAg) was determined by a complement fixation technique (Lee et al., 1974). Of the G-6-PD-normal patients 12 were negative, three anticomplementary, and five positive for $\mathrm{HBAg}$. Only four of the 18 G-6-PD-deficient subjects were so studied; two were negative and two anticomplementary for $\mathrm{HBAg}$. In so far as haemolysis was concerned the subjects with demonstrable HBAg were in no way distinct from the others. Of the G-6-PD-normal patients four were observed from the first week, 12 from the second week, two from the third week, and two from the fourth week of their illness. Of the G-6-PDdeficient patients seven were observed from the first week, eight from the second week, one from the third week, and two from the fourth week of their illness. Hence the two groups were roughly comparable with regard to the duration between the onset of their illness and admission to hospital.

Haemoglobin levels and reticulocyte counts were determined three times a week during the first week after admission and then twice weekly until discharge or death. The reticulocyte count was corrected for changes in the packed red cell volume and expressed as the absolute count (Hillman and Finch, 1969). A sudden decrease in haemoglobin of more than $1.5 \mathrm{~g} / \mathrm{dl}$ or an absolute reticulocyte count of above $2 \%$ was taken as evidence of haemolysis. The haemoglobin pattern and haemoglobin $\mathrm{F}$ levels were determined and Coombs antiglobulin test was performed by standard methods (Dacie and Lewis, 1968) in all cases studied. The level of reduced glutathione (GSH) and its stability after two hours of incubation with acetylphenylhydrazine were determined by the method of Beutler et al. (1963) and erythrocyte G-6-PD levels by a previously reported technique (Chan et al., 1965).

Autologous red cell survival studies were performed using ${ }^{51} \mathrm{Cr}$ labelling in 10 subjects (six G-6-PD-normal and four G-6-PD-deficient) in the first or second week of their clinical illness. In addition the survival of compatible red cells from G-6-PD-deficient subjects in the steady state who were not suffering from any other illness was studied in four of the G-6-PD-normal subjects with viral hepatitis during their second week of illness. As the decrease in ${ }^{51} \mathrm{Cr}$ activity did not follow a single exponential curve in five instances its half disappearance time ( $\left.t \frac{1}{2}\right)$ was used in all studies (I.C.S.H. Panel, 1971).

One of the G-6-PD-normal patients died from acute massive hepatic necrosis. In the three G-6-PD-deficient patients who died after severe intravascular haemolysis no evidence of massive hepatic necrosis was found at necropsy and death was due to disseminated intravascular haemolysis and renal failure.

\section{Results}

Fourteen of the 20 G-6-PD-normal patients and 17 of the 18 G-6-PD-deficient patients had clinical evidence of haemolysis during the course of their illness (table I). Of the G-6-PDdeficient patients eight had haemoglobin levels below $9 \mathrm{~g} / \mathrm{dl}$, whereas in none of the G-6-PD-normal patients was the haemoglobin level this low. The four patients with haemoglobin levels below $7 \mathrm{~g} / \mathrm{dl}$ had marked haemoglobinuria, and three of these died after acute massive intravascular haemolysis. The greatest fall in haemoglobin occurred in the first week or at the beginning of the second week of the illness. Only three of the G-6-PDnormal patients had serum bilirubin levels exceeding 342 
$\mu \mathrm{mol} / 1(20 \mathrm{mg} / 100 \mathrm{ml})$ compared with 11 of the G-6-PDdeficient patients. Only one of the G-6-PD-normal patients had an SGPT level exceeding 500 Reitman-Frankel units compared with seven of the G-6-PD-deficient patients. The changes in SGOT levels followed a similar pattern.

Analysis of the patients' lowest haemoglobin levels and absolute reticulocyte counts (fig. 1) showed a significant $(P<0.01)$ inverse relationship except in the case of the four G-6-PDdeficient patients with haemoglobinuria when the values were outside the $95 \%$ tolerance limit. A significant inverse relationship was a!so shown between the lowest haemoglobin levels and the highest bilirubin levels in the G-6-PD-deficient patients (fig. 2) $(P<0.05)$ but no relationship was apparent in the G-6-PDnormal patients. There was no significant relationship between the lowest haemoglobin level or the highest bilirubin level and the highest serum transaminase level in either group of patients.

Erythrocyte GSH levels, GSH stability, and the $t \frac{1}{2}$ of ${ }^{51} \mathrm{Cr}$ labelled autologous red cells in six G-6-PD-normal and four G-6-PD-deficient patients are shown in table II. Erythrocyte GSH and GSH stability were normal in the G-6-PD-normal patients. Two of the four G-6-PD-deficient patients had low GSH levels $(0.5$ and $0.7 \mathrm{mmol} / 1(16.5$ and $21.0 \mathrm{mg} / 100 \mathrm{ml})$ respectively) and both had massive intravascular haemolysis. The $t \frac{1}{2}$ of ${ }^{51} \mathrm{Cr}$-labelled red cells in the six patients with normal G-6-PD levels varied from 16 to 19 days. Two of these patients had no clinical evidence of haemolysis. Of the G-6-PDdeficient patients the two with no haemoglobinuria had $t \frac{1}{2}$ values of 15 and 19.5 days respectively, while the two with

TABLE I-Haematological Data and Results of Liver Function Tests in Patients with Viral Hepatitis

\begin{tabular}{|c|c|c|c|c|c|}
\hline & & & & G-6-PD-normal & G-6-PD-deficien \\
\hline No. studied: & . & .. & . $\quad \ldots$ & 20 & 18 \\
\hline $\begin{array}{l}\text { Lowest haemoglobin } \\
<5 \text { to } 7 \\
57 \text { to } \\
>7 \\
>9 \text { to } 12 \\
>12\end{array}$ & $\begin{array}{l}\text { leve } \\
\because \\
\because \\
\cdots \\
\cdots\end{array}$ & $\begin{array}{l}(\mathrm{g} / \mathrm{d} \\
\cdots \\
\cdots \\
\cdots \\
\cdots\end{array}$ & $\begin{array}{ll}. & . \\
\because & \\
\because & \\
. & \\
. & \end{array}$ & $\begin{array}{r}0 \\
0 \\
0 \\
6 \\
14\end{array}$ & $\begin{array}{l}2^{*} \\
2^{*} \\
4 \\
8 \\
2\end{array}$ \\
\hline 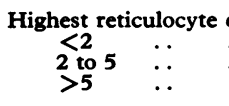 & $\begin{array}{l}\text { coun } \\
\cdots \\
\cdots \\
\cdots\end{array}$ & $\begin{array}{l}\text { (abs } \\
\cdots \\
\cdots \\
\cdots\end{array}$ & $\begin{array}{ll}\text { ste } \% \text { ): } & \\
\ldots & \ldots \\
\ldots & \cdots \\
\cdots & \cdots\end{array}$ & $\begin{array}{r}6 \\
12 \\
2\end{array}$ & $\begin{array}{l}4 \\
6 \\
8\end{array}$ \\
\hline $\begin{array}{r}\text { Highest bilirubin lev } \\
34 \text { to } 171 \text { [t } \text { to } \\
>171 \text { to } 342[\text { [ } \\
>342[>20 \mathrm{mg}\end{array}$ & $\begin{array}{l}\text { vel }(\mu \\
\text { tolon } \\
\text { s10 t } \\
\text { g/100 }\end{array}$ & $\begin{array}{l}\text { ol/1 } \\
\text { g/10 } \\
\text { all] }\end{array}$ & $\begin{array}{c}\text { nl] } \\
{[100 \mathrm{ml}] .} \\
\ldots\end{array}$ & $\begin{array}{r}14 \\
3 \\
3\end{array}$ & $\begin{array}{r}4 \\
3 \\
11\end{array}$ \\
\hline $\begin{array}{c}\text { Highest SGPT (Reit } \\
<100 \text {. } \\
>200 \text { to } 500 \\
>500 \quad \ldots\end{array}$ & $\begin{array}{l}\text { itman- } \\
\cdots \\
\cdots \\
\cdots\end{array}$ & $\begin{array}{l}F r a n \\
\cdots \\
\cdots \\
\cdots\end{array}$ & $\begin{array}{ll}\text { units): } \\
\ldots & \ldots \\
\ldots & \cdots \\
\ldots & \cdots\end{array}$ & $\begin{array}{r}2 \\
7 \\
10 \\
1\end{array}$ & $\begin{array}{l}1 \\
1 \\
9 \\
7\end{array}$ \\
\hline
\end{tabular}

*Associated with frank haemoglobinuria.

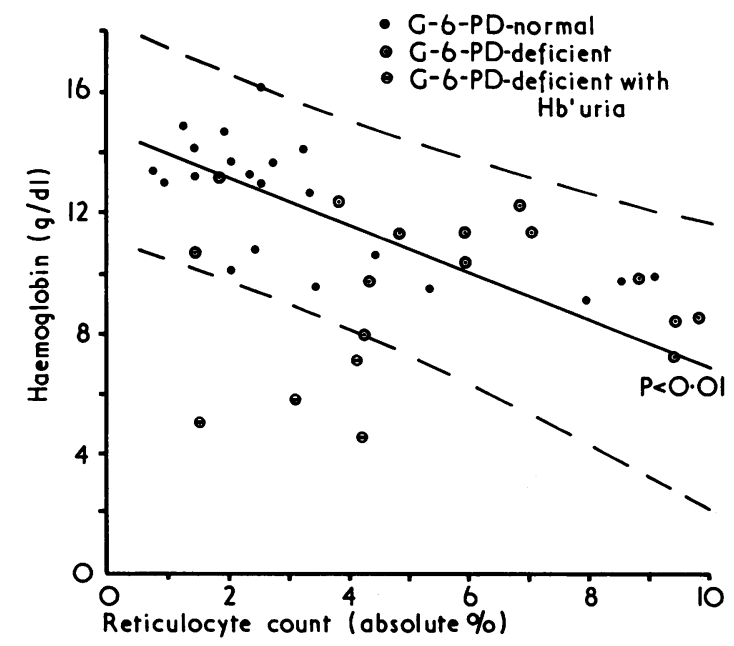

FIG. 1-Relationship between lowest haemoglobin levels and highest absolute reticulocyte counts in patients with viral hepatitis. Continuous line represents linear regression for G-6-PD-normal subjects $(P<0.01)$ and dotted lines include $95 \%$ tolerance limits.

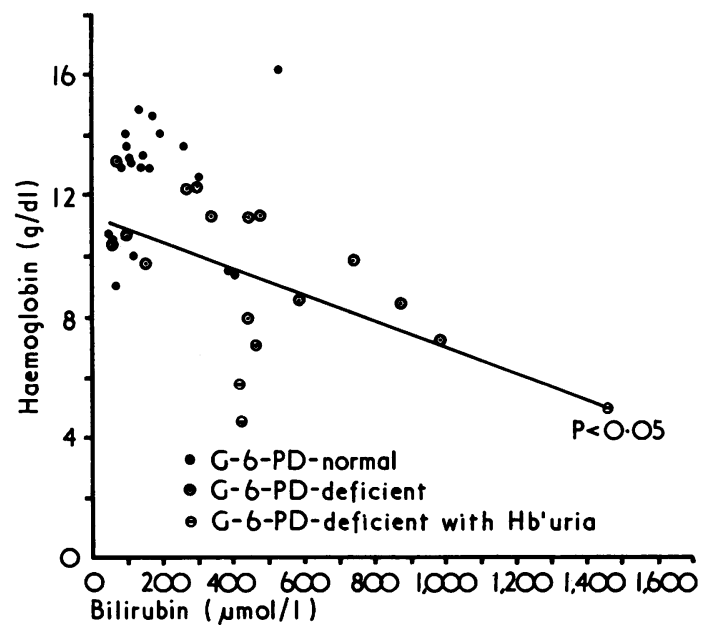

FIG. 2-Relationship between lowest haemoglobin levels and highest total bilirubin levels in patients with viral hepatitis. Continuous line is linear regression for G-6-PD-deficient subjects $(\mathrm{P}<0.05)$.

Conversion: SI to Traditional Units-Serum bilirubin: $100 \mu \mathrm{mol} / 1 \simeq 6 \mathrm{mg} / 100 \mathrm{ml}$.

TABLE II-Reduced Glutathione (GSH) and ${ }^{51}$ Cr-erythrocyte survival in Two Groups of Patients with Viral Hepatitis

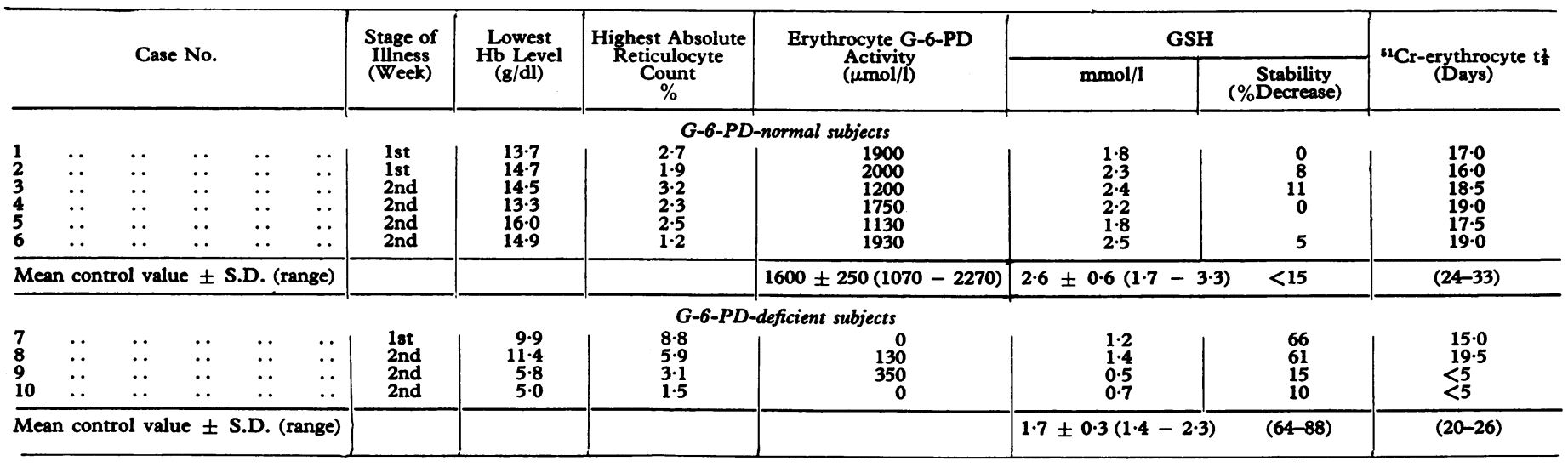

Conversion: SI to Traditional Units-Glutathione (reduced): $1 \mathrm{mmol} / 1 \simeq 31 \mathrm{mg} / 100 \mathrm{ml}$. 
haemoglobinuria had values of less than five days. The $t \frac{1}{2}$ in normal control subjects in this laboratory ranges from 24 to 33 days and that in G-6-PD-deficient subjects in the steady state 20 to 26 days (Chan et al., 1971).

When ${ }^{51} \mathrm{Cr}$-labelled compatible G-6-PD-deficient red cells were transfused into four G-6-PD-normal patients with viral hepatitis the $t \frac{1}{2}$ values were $17,18,20$, and 22 days respectively. The values for G-6-PD-deficient cells in 18 compatible G-6-PDnormal subjects not suffering from viral hepatitis varied from 19 to 35 days (Chan and Todd, unpublished).

The haemoglobin pattern and haemoglobin $F$ levels were normal and the Coombs antiglobulin test result was negative in all patients.

\section{Discussion}

This study confirms previous reports (Pitcher and Williams, 1963; Kattamis and Tjortjatou, 1970) that a mild to moderately severe haemolysis occurs in G-6-PD-normal subjects suffering from viral hepatitis. In the present series of patients the anaemia was not severe, the haemoglobin levels being over $9 \mathrm{~g} / \mathrm{dl}$ and the $t^{\frac{1}{2}}$ of ${ }^{51} \mathrm{Cr}$-labelled red cells varied from 16 to 19 days (normal range 24 to 33 days). The increase in the absolute reticulocyte count was appropriate in the 20 patients studied, indicating adequate erythropoiesis in the bone marrow. The cause of the haemolysis, however, was not determined. Red cell GSH was normal in amount and stable and in no case was there a positive Coombs test result or evidence of coincidental thalassaemia.

Eight of the 18 G-6-PD-deficient patients had clinically more severe haemolysis than the G-6-PD-normal patients (table I) but in most recovery was uneventful. The higher bilirubin levels in the G-6-PD-deficient patients were at least partly due to a more-pronounced haemolysis as evidenced by a significant inverse relationship between the lowest haemoglobin levels and the serum bilirubin levels in this group (fig. 2). The higher serum transaminase levels could also have been caused by the more severe anaemia (Wilkinson, 1962). Studies of the survival of the G-6-PD-deficient red cells in patients with viral hepatitis, however, of which two were autologous and four entailed cross-transfusion into G-6-PD-normal recipients, showed that the ${ }^{51} \mathrm{Cr} t \frac{1}{2}$ values were shortened but to an extent similar to that seen with G-6-PD-normal red cells (table II). The comparable results in the cross-transfusion group indicated that the relatively good red cell survival time in the two patients transfused with autologous cells was not due to younger and less vulnerable cells being used for study. The discrepancy between these results and the observation that haemolysis was more marked in the G-6-PD-deficient group may be attributed to the fact that the red cell survival studies were carried out one to two weeks after the onset of the clinical hepatitis, whereas in the G-6-PD-deficient patients the maximum fall in haemoglobin level and rise in reticulocyte count occurred in the first week or at the beginning of the second week of the illness.

In four of the G-6-PD-deficient patients acute massive intravascular haemolysis occurred. Unlike the rest of the group they had relatively low reticulocyte counts, indicating some degree of depressed bone marrow erythropoietic activity. In addition the red cell GSH levels were low. Though it has been reported that GSH levels are low in uraemia (Thiel et al., 1961) we have been unable to confirm this. Out of 10 G-6-PD-normal patients with uraemia before dialysis four with acute renal failure had GSH levels between 1.9 and $2.8 \mathrm{mmol} / 1(57.2$ and $87.2 \mathrm{mg} / 100 \mathrm{ml}$ ) and six with chronic renal failure had GSH levels between 1.6 and $2.6 \mathrm{mmol} / 1(49.3$ and $81.0 \mathrm{mg} / 100 \mathrm{ml})$ (normal: $1 \cdot 7-3.3 \mathrm{mmol} / 1 ; 53-100 \mathrm{mg} / 100 \mathrm{ml}$ ) (Chan and Todd, unpublished). In none did the GSH level decrease significantly after incubation with acetylphenylhydrazine for two hours. Therefore, it is unlikely that uraemia per se was the cause of the low GSH levels: On the other hand, all the four patients had taken a multiplicity of drugs which included paracetamol, amidopyrine, and others of undetermined nature during the preicteric stage of their illness, so that an additional oxidative stress may have been responsible for the low GSH levels and acute massive haemolysis. The necropsy results indicated that death in the three was not due to a more fulminating form of hepatitis. Therefore, while oxidant drugs should be avoided by all G-6-PD-deficient patients this is of particular importance in those with low enzyme levels who have or may have viral hepatitis.

\section{References}

Beutler, E., Duron, O., and Kelly, B. M. (1963). Fournal of Laboratory and Clinical Medicine, 61, 882

Chan, T. K., and Todd, D. (1972). American fournal of Human Genetics,

24, 475. Clinical'Medicine, 66, 937.

Chan, T. K., et al. (1971). Fournal of Laboratory and Clinical Medicine, 77,

Clearfield, H. R., Brody, J. I., and Tumen, H. J. (1969). Archives of Internal Medicine, 123, 689 .

Dacie, J. V., and Lewis, S. M. (1968). Practical Haematology, 4th edn. London, Churchill.

Hillman, R. S., and Finch, C. A. (1969). British fournal of Haematology, 17, 313

I. C. S. H. Panel (1971). British fournal of Haematology, 21, 241

Kattamis, C. A., and Tjortjatou, F. (1970). Fournal of Pediatrics, 77, 422

Lee, A. K. Y., Tse, T. F., and Mok, C. K. (1974). Australian and New Zealand fournal of Medicine, 4, 8.

Phillips, S. M., and Silvers, N. P. (1969). Annals of Internal Medicine, 70, 99.

Pitcher, C. S., and Williams, R. (1963). Clinical Science, 24, 239.

Salen, G., et al. (1966). Annals of Internal Medicine, 65, 1210.

Thiel, G. B., Brodine, C. E., and Doolan, P. D. (1961). Fournal of Laboratory and Clinical Medicine, 58, 736.

Wilkinson, J. H. (1962). An Introduction to Diagnostic Enzymology, p. 140. London, Arnold.

\section{MEDICAL MEMORANDA}

\section{Frusemide-induced Pancreatitis}

\section{P. E. JONES, M. H. OELBAUM}

\section{British Medical fournal, 1975, 1, 133-134}

Frusemide is a commonly used diuretic which inhibits sodium reabsorption in the ascending limb of the loop of Henle and probably in other segments of the tubule. We report here a case of acute pancreatitis in which frusemide was strongly implicated as the aetiological agent.

Manchester Northern Hospital, Manchester 8

P. E. JONES, M.B., M.R.C.P., Senior House Officer (Present appointment: Registrar, Medical Unit, University College Hospital, London WC1E 6JJ) M. H. OELBAUM, M.D., F.R.C.P., Consultant Physician

\section{Case Report}

A 64-year-old housewife was admitted to hospital having sustained a myocardial infarction complicated by mild left ventricular failure. She had a history of anterior chest pain radiating to the left arm. On admission the patient's condition was good; her pulse was regular at 80 beat $/ \mathrm{min}$, and her blood pressure was $150 / 90 \mathrm{~mm}$ Hg. A fourth heart sound was audible at the apex and crepitations were heard at the lung bases. Her medical records showed that the patient had once developed a transitory drug rash after removal of uterine polyp, but no record of the offending drug had been made.

\section{INVESTIGATIONS AND TREATMENT}

Serum aspartate aminotransferase was $50 \mathrm{U} / \mathrm{ml}$ (normal $<40$ $\mathrm{U} / \mathrm{ml}$ ), and serum lactic dehydrogenase was $1200 \mathrm{U} / \mathrm{ml}$ (normal 